\title{
The Position of Convict as Justice Collaborator in Revealing Organized Crime
}

\author{
Bambang Sugiri", Nurini Aprilianda**, Hanif Hartadi ${ }^{* * *}$ \\ DOI: https://doi.org/10.22304/piih.v8n2.a5
}

Submitted: April 21, 2021 | Accepted: July 30, 2021

\begin{abstract}
This article aims to examine the position of the convict as justice collaborator in revealing organized crime. A justice collaborator can assist law enforcement officers. The background of the study is the concept of crown witness, which is often used in proving criminal cases, even though it violates human rights. A difficulty in revealing organized crime is that perpetrators mostly do not disclose their criminal network and the parties involved. Information from the convict related to the network of the crime they committed makes law enforcement officers easier to reveal the organized crime. This study used a juridical analysis with an approach to laws and regulations, conceptual method, and comparative method. The results of the study show that convict who chose to become a justice collaborator has a vital role. Law enforcement officers can take advantage of this role in exposing organized crimes without human rights violations to the convict. The convict can have a reward in the form of parole and additional remissions.
\end{abstract}

Keywords: convicts, justice collaborator, organized crime.

\section{Kedudukan Narapidana sebagai Justice Collaborator dalam Pengungkapan Kejahatan Terorganisir}

\begin{abstract}
Abstrak
Artikel ini bertujuan mengkaji kedudukan narapidana sebagai justice collaborator dalam pengungkapan kejahatan terorganisir yang dapat membantu tugas aparat penegak hukum. Hal ini dilatarbelakangi konsep saksi mahkota yang sering dipergunakan dalam pembuktian perkara pidana namun dinilai melanggar HAM. Kesulitan pengungkapan kejahatan teroganisir adalah para pelaku yang terlibat tidak mengungkapkan jaringan kejahatannya serta pihak yang terlibat. Informasi dari narapidana terkait jaringan kejahatan yang pernah dilakukannya, memudahkan pengungkapan kejahatan terorganisir oleh aparat penegak hukum. Pada penulisan ini penyusunan dilakukan dari hasil analisis yuridis melalui sebuah pendekatan peraturan-peraturan undang-undang, metode konseptual dan juga mempergunakan metode perbandingan. Adapun hasil dari penelitian memperlihatkan

PADJADJARAN Journal of Law Volume 8 Number 2 Year 2021 [ISSN 2460-1543] [e-ISSN 2442-9325]

* Lecturer of the Faculty of Law. Universitas Brawijaya, Jl. MT.Haryono 169 Malang, S1 (Universitas Brawijaya), S2 (Universitas Indonesia), S3 (Universitas Brawijaya), bambang.sugiri@ub.ac.id.

** Lecturer of the Faculty of Law, Universitas Brawijaya, and a Researcher at PERSADA LPPM UB, J. MT. Haryono 169 Malang, S1 (University of Brawijaya), S2 (Universitas Brawijaya), S3 (Universitas Airlangga), nurini.aprilianda@ub.ac.id.

*** Postgraduate Student of the Faculty of Law, Universitas Brawijaya, and an Attorney at the Office of the Attorney General of the Republic of Indonesia, S1 (University of Brawijaya), hanif.hartadi@kejaksaan.go.id.
\end{abstract}


bahwa narapidana sebagai justice collaborator memiliki peran yang dapat dimanfaatkan oleh aparat penegak hukum dalam mengungkap kejahatan terorganisir tanpa dinilai melakukan pelanggaran HAM kepada narapidana karena adanya pemberian penghargaan berupa pembebasan bersyarat dan remisi tambahan.

Kata Kunci: justice collaborator, kejahatan terorganisir, narapidana.

\section{A. Introduction}

The United Nations' Convention against Transnational Organized Crime defines organized crime as follows: ${ }^{1}$

"Organized criminal group shall mean a structured group of three or more persons, existing for a period of a time and acting in concert with the aim of committing one or more serious crimes or offenses established in an accordance with this Convention, in order to obtain, directly, a financial or other material benefit."

In the laws and regulations in Indonesia, the Law Number 35 of 2009 on Narcotics defines organized crime as a crime that is committed by a structured group consisting of three or more people who have existed for a certain time and act together to commit a narcotic-related crime. ${ }^{2}$ In fact, crimes of illicit narcotics trafficking, corruption, terrorism, and violations of human rights are some examples of crimes that can then be categorized as organized crime. The effort to reveal organized crime should be able to dismantle the criminal network up to the arrest of the main perpetrator, so that the organized crime can be ascertained not to commit another crime.

Some examples that are categorized as organized crime can also be attributed to white-collar crimes. White-collar crime is a crime committed by elites, businessmen, bankers, or officials who have strategic roles and functions or access strategic policies through corruption, fraud, or scam that are very destructive and cause mass victims. ${ }^{3}$ White-collar crimes cannot be committed alone. There must be cooperation among the perpetrators to commit them. Therefore, white-collar crimes can be included in organized crimes.

The obstacle in revealing organized crime is when the perpetrator keep secret or do not provide information regarding their criminal network. The origins of organized crime activities can be traced to the mafia, which is a syndicate or group of criminals. The group is the oldest and the largest group that ever existed in Italy. The group is also known as the Sicilian Mafia or Cosa Nostra. Their crimes are to commit organized crimes. The perpetrators are called the mafioso. The term

Article 2 (B) Annex I, United Nations Convention Against Transnational Organized Crime 2000.

Article 1 Number 20 of Law Number 35 of 2009 on Narcotics.

Frassminggi Kamasa, "Kejahatan Kerah Putih, Kontraterorisme dan Perlindungan Hak Konstitusi Warga

Negara dalam Bidang Ekonomi", Jurnal Konstitusi, Vol. 11, No. 4, December 2014, p. 783. 
mafioso is the designation of the members of the mafia in Italia. The main evil act that the mafiosos do is the heroin trade, which then spreads to countries in the world. Similar organized crime groups exist in other countries, such as the Mafiya in Russia, the Cartel in Colombia, the Triad in China, and the Yakuza in Japan. The existence of such a strong criminal organization allows the members to be able to exist, to control, and to enter many sides of power, ranging from state administration sector (executive), legislative, and judicial sectors where law enforcement officers work. ${ }^{4}$ To reveal organized and corporate crime, there are many obstacles in tracking and processing detection and prosecution due to an imbalance of professionalism between the legal apparatus group and the criminal group. ${ }^{5}$

Initially, law enforcement officers could reveal organized crimes by maximizing the role of crown witness (kroongetiige). ${ }^{6}$ The concept was an implementation of Article 142 of the Law Number 8 of 1981 on the Criminal Procedure Code (hereinafter referred to as the Criminal Procedure Code), especially the part that regulates the splitting of case files. However, the concept of crown witness was considered as a violation on human rights. Huda states that an investigator cannot determine a person as a suspect only based on the testimony of the crown witness, ${ }^{7}$ if the determination of the suspect is based on a new investigation order issued by the investigator. ${ }^{8}$

In addition to Huda's opinion, Dahlan presents two additional expert witnesses who are also criminal law experts: Mudzakir and Weda. The two experts also propose the same idea with Huda. They believe that investigators cannot identify a person as a suspect based on the testimony of the crown witness. ${ }^{9}$ The opposing opinion occurs because the concept of crown witnesses is contrary to the concept of human rights. One of the reasons is the creed of human rights that someone cannot be compelled to testify against themselves or to confess guilt. In other words, someone cannot be forced to give a testimony that can incriminate a perpetrator of the crime or be forced to admit a mistake. The principle is known as

4 Hariman Satria, "Menakar Perlindungan Justice Collaborator, Quo Vadis Justice Collaborator", Jurnal Konstitusi, Vol. 13, No. 2, 2016, p. 444.

5 Henry Donald Lbn. Toruan, "Pertanggungjawaban Pidana Korporasi”, Jurnal Rechts Vinding, Vol. 3, No. 3, 2014, p. 404.

$6 \quad$ Firman Wijaya, Whistleblower dan Justice Collaborator dalam Perspektif Hukum, Jakarta: Penaku, 2012 , p. 11.

7 Dani Prabowo, "Kejati DKI: Penggunaan Saksi Mahkota Masih Jadi Perdebatan", https://nasional.kompas.com/read/2015/07/31/08195591/Kejati.DKI.Penggunaan, accessed on February 2020.

$8 \quad$ lbid.

$9 \quad$ lbid. 
a non-self-incrimination principle..$^{10}$ In addition, the concept is also considered to be contrary to the Criminal Procedure Code. Article 189 (3) of the Criminal Procedure Code stipulates that the testimony of a person who is being charged can only be used for themself. It can be interpreted that the information cannot be used for other perpetrators.

Facing the challenges of professionalism and the obligation to uphold human rights in law enforcement, especially in the evidentiary process through the testimony of witnesses, it is necessary to make legal innovations that can support the evidentiary process by incorporating new provisions and ideas. ${ }^{11}$ According to Rahardjo, the eradication of extraordinary crimes needs extraordinary methods. ${ }^{12}$ One of the methods is the concept of Justice Collaborator.

The idea of justice collaborator is not the original Indonesian method. ${ }^{13}$ The idea is a concept to use information from a perpetrator of organized crime, which is similar to the concept of a crown witness. The concept of collaboration between criminal and law enforcement officers is often referred to as justice collaborator. Indonesian positive law only recognizes the concept of a witness, who is also a perpetrator of the criminal act in collaboration with law enforcement. ${ }^{14}$ The practice is a legal collaboration between a perpetrator of the criminal act and law enforcement officers. The perpetrator provides useful information for the process of case disclosure to law enforcement officers. The law enforcement officers subsequently dismantle the criminal networks. It is expected that a good legal system can support law enforcement efforts. The involvement of justice collaborator is assumed to be able to uncover 'untouchable actors'. ${ }^{15} \mathrm{~A}$ justice collaborator can get benefits in the form of protection and awards. A form of protection is safety for both the collaborator and the family. The award can be in the form of leniency in criminal sanctions or remissions and parole. ${ }^{16}$

In current Indonesian legal regulation, there are no clear regulations regarding justice collaborators. According to the literature the definition of justice collaborator is "a criminal who provides assistance to law enforcement to uncover the crime in which he is involved". The term is witness perpetrator (saksi-pelaku) as specified in Article 1 Number (2) of the Law Number 31 of 2014 on the Amendments to the Law Number 13 of 2006 on the Protection of Witnesses and

10 I Made Sukadana (et.al), “Alat Bukti Keterangan Saksi Mahkota dalam Perkara Pidana Pencurian”, Jurnal Law Reform, Vol. 14, No. 2, 2014, p. 268.

11 Ross Poole, Moralitas dan Modernitas, di Bawah Bayang-Bayang Nihilisme, Yogyakarta: Kanisius, 1993, p. 23.

12 O. C. Kaligis, Antologi Tulisan Ilmu Hukum Jilid 1, Bandung: PT Alumni, 2007, p. 89.

13 Andi Andojo Soetjipto, Menyongsong dan Tunaikan Tugas Negara Sampai Akhir: Sebuah Memoar, Jakarta: Granit, 2007, p. 167.

14 Article 1 Number 2 of the Law Number 31 of 2014 on the Amendments to the Law Number 13 of 2006 on the Protection of Witnesses and Victims.

15 Andi Hamzah, Pemberantasan Korupsi melalui Hukum Pidana Nasional dan Internasional, Edisi Revisi, Jakarta: Raja Grafindo Persada, 2007, p. 84.

16 Article 10A of the Law Number 31 of 2014 on the Amendments to the Law Number 13 of 2006 on the Protection of Witnesses and Victims. 
Victims. The Law Number 31 of 2014 indeed changes the scope of justice collaborator by giving right and opportunity to convict to become a justice collaborator. The provision had triggered a debate. A legal expert and criminologist, Meliala, argues that the status of justice collaborator can only be carried out in the pre-adjudication and adjudication phases.

Another debate covers the procedure for granting the right to parole and additional remission to convict who is designated as justice collaborator. The debate involved the Witness and Victim Protection Agency (LPSK - Lembaga Perlindungan Saksi dan Korban) and law enforcement agencies such as the Indonesian National Police, the Attorney General Office, the Corruption Eradication Commission (KPK - Komisi Pemberantasan Korupsi), and the National Narcotics Agency (BNN - Badan Narkotika Nasional).

This study is of the position to observe the arrangement of the convict as justice collaborator in Indonesia. This study used a normative juridical method, an approach to the rule of law or legislation (statute approach) through the study of various laws and regulations relating to the legal issues being handled. ${ }^{17}$ In addition, this study also employed a conceptual approach through doctrines that experience legal dynamics. The study aims to generate an idea. This study is expected to produce legal definitions, some legal concepts, and some legal principles that are in line with the issues at hand.

\section{B. The Concept of Justice Collaborator}

The concept of justice collaborator is an effort to investigate a criminal act categorized as serious and organized - for example, corruption, narcotics, terrorism, money laundering, etc. ${ }^{18}$ Initially, the justice collaborator was a facility for a witness-perpetrator who was willing to carry out legal collaboration with law enforcement officers. In 1970, the United States was the first country to do it. The facility is an effort to eradicate organized mafia, which is known for their omerta, an oath of the member to keep silent. It is the oldest rule in mafioso groups of Sicily. ${ }^{19}$ Some organized crimes bring big impact on society, such as narcotics crime. Another a big impact is crimes that endanger the state's security, such as terrorism crimes. Justice collaborator is a concept that can be used by all law enforcement agencies to reveal organized crimes.

17 Peter Mahmud Marzuki, Penelitian Hukum, Jakarta: Kencana, 2015, p. 133.

18 Number 1 of the Circular of The Supreme Court of the Republic of Indonesia (SEMA) Number 11 of 2011 on the Treatment for Criminal Acts/Whistleblowers and Witnesses who are justice collaborators in Certain Criminal Cases.

19 Lilik Mulyadi, Perlindungan Hukum Whistleblower \& Justice Collaborator dalam Upaya Penanggulangan Organized Crime, Bandung: PT Alumni, 2015, p. 5. 
Article 37 paragraph (2) of the 2003 United Nations Convention Against Corruption (UNCAC), that has been ratified by the Indonesian government in the Law Number 7 of 2006 (on the Ratification of the 2003 United Nations Convention Against Corruption) reads as follows: ${ }^{20}$

"Each state party shall consider providing for the possibility, in appropriate cases, of mitigating punishment of an accused person who provides substantial cooperation in the investigation or prosecution of an offense established in accordance with this convention."

Therefore, in certain cases, each participant must consider the mitigation for the defendant who cooperate in the investigation process as specified in the 2003 UNCAC convention.

Article 37 paragraph (3) of the Convention reads as follows: ${ }^{21}$

"Each state party shall consider providing for the possibility, in accordance with fundamental principles of its domestic law, of granting immunity from prosecution to a person who provides substantial cooperation in the investigation or prosecution of an offense established in accordance with this convention."

The article means that each state party has an obligation to consider the possibility, in accordance with the basic principles of its domestic law, to provide immunity from prosecution for persons who provide substantial cooperation in the investigation or prosecution of a criminal offense.

The term justice collaborator refers to a criminal who assist law enforcement to reveal criminal case. Commonly, the term is also known as cooperative whistleblowers or participant whistleblowers. ${ }^{22}$ In Indonesia, there are no regulations that clearly mention the terms whistleblower and justice collaborator. ${ }^{23}$ The definition of justice collaborator, according to the literature, refers to a criminal who assists law enforcement officers for the purposes of disclosing criminal acts, in which that person is also involved. The term equals to the term witness-perpetrator (saksi-pelaku) in the Law Number 31 of 2014 on the Amendments to the Law Number 13 of 2006 on the Protection of Witnesses and Victims.

Protection of witnesses and victims in Indonesia is currently based on the Law Number 31 of 2014 on the Amendments to the Law Number 13 of 2006 on the Protection of Witnesses and Victims. The law also stipulates the establishment of

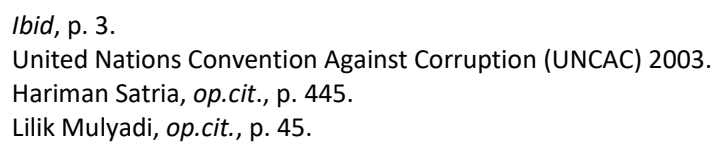


the Witness and Victim Protection Agency (LPSK - Lembaga Perlindungan Saksi dan Korban). The legal protection to a justice collaborator covers: ${ }^{24}$

1. Protection of security for the perpetrator, their family, and their property;

2. Confidentiality of identity and/or obtaining a new identity;

3. Obtaining a temporary and/or new residence; and

4. Immunity to the law in the form of exclusion from prosecution legally due to testimony as a witness, which, in the process, is given with good intentions.

A justice collaborator is also entitled to different treatment that includes ${ }^{25}$

1. Differentiation of the detention room or place for serving a sentence;

2. Separation of case files; and

3. Give testimony in the absence of the accused.

Both protection and special treatment for justice collaborator is intended so that they can provide information without threats from testimonies that are or will be given to law enforcement officials. This is due to the potential threat from parties who feel displeased when their criminal network is dismantled. This form of protection and appreciation is intended so that criminals are interested in cooperating with law enforcement officials in dismantling their criminal networks.

\section{Arrangement and Determination of Justice Collaborator Status for Convict}

Human behavior changes over time, including the development of information technology. The behavior of criminals also follows a more sophisticated pattern to be more organized with the utilization of increasingly developing technology. Thus, the procedures for disclosing cases of organized crime can be increasingly difficult. The concept of justice collaborator is considered to facilitate the work of law enforcement officers to disclose a crime or criminal act that is categorized as an organized crime that has a large impact. This concept has its origins in the United States. It was initially intended to tackle criminal groups (mafia).

An organized crime is sometimes associated with the term white-collar crime. Some cases seem more difficult to be revealed than some others. Some obstacles are as follows. ${ }^{26}$

1. There is difficulty to know who the main perpetrator of the crime.

\footnotetext{
24 Article 5 of the Law Number 31 of 2014 on the Amendments to the Law Number 13 of 2006 on the Protection of Witnesses and Victims.

25 Ibid.

26 The Academic Manuscript of the Draft of Law Number 31 of 2014 on the Amendments to the Law Number 13 of 2006 on the Protection of Witnesses and Victims, pp. 19-20.
} 
2. In some cases, the people, who were previously considered to have understood about the case and were involved, obtain some benefits from the criminal act. They would have been almost impossible to report the crime to the authorized party.

3. The perpetrators of criminal acts mostly use the correlation between the main criminals. The correlation can only be proven with an assistance from people involving in the correlation.

4. Some cases find difficulties in finding a definite "scene of the crime" or even were limited by the amount of forensic evidence to identify the perpetrator.

5. The perpetrator of a major case can hide, destroy, and transfer tangible or physical evidence, for example, transaction documents and assets purchased from the proceeds of corruption crimes. The evidence may also be entrusted to someone else.

6. In some cases, perpetrators of crimes are people who have power. The power can be used to influence the investigation process, including suppressing witnesses and even harassing witnesses who collaborate with law enforcement.

7. Sometimes, law enforcement officers find out a crime that has occurred for a long time. Then, the investigation process has the problem to trace the crime since the evidence had been disappeared. Some of the evidences are even difficult to find, and the witnesses have been paid or have the potential to give false testimony.

Indonesia is a member-state of the 2003 United Nations Convention Against Corruption that has ratified the convention by the establishment of the Law Number 7 of 2006 on the ratification of UNCAC. In line with the ratification process, Indonesia must provide protection and reduced penalties and even provide immunity to whistleblowers and justice collaborators. Several similar regulations are also found in Article 26 of the 2000 United Nation Convention Against Transnational Crimes. ${ }^{27}$

As a follow-up to the ratification of the convention, the executive and the legislative generated the Law Number 13 of 2006 on the Protection of Witnesses and Victims. The Law is the first law that regulates protection for a justice collaborator. In its development, it was changed and added through the Law Number 31 of 2014 on the Amendments to the Law Number 13 of 2006 on the Protection of Witnesses and Victims.

The change of laws and regulations on the of witnesses and victims has explicitly expanded the boundaries of parties who can be granted justice collaborator status. Initially, only suspects and defendants were eligible for the status of convicts or defendants. Edyono argues that in Article 10 paragraph (2) of

27 Number 2 Supreme Court Circular Letter (SEMA) No. 4 of 2011 on the Treatment of Whistleblowers and Witnesses of Cooperating Perpetrators (Justice Collaborators) in Certain Criminal Acts. 
the Law Number 13 of 2006 in conjunction with the Law Number 31 of 2014 has weaknesses. ${ }^{28}$ Edyono states as follows. ${ }^{29}$

"Seorang yang dapat di posisikan sebagai Justice colaborators adalah pertama kalinya ia haruslah seorang saksi yang juga sebagai tersangka, ini berarti posisi dari orang tersebut haruslah sebagai saksi seperti yang dimaksud dalam Undang-undang Nomor 13 tahun 2006, yaitu Saksi adalah orang yang dapat memberikan keterangan guna kepentingan penyelidikan, penyidikan, penuntutan, dan pemeriksaan di sidang pengadilan tentang suatu perkara pidana yang ia dengar sendiri, ia lihat sendiri, dan/atau ia alami sendiri yang dalam posisi lainnya juga adalah seorang tersangka."

[A person who can be designated as a Justice collaborator must be a witness who is also a suspect. It means that the position of the person must be a witness as referred to in the Law Number 13 of 2006. A witness is a person who can provide information for the purposes of inspection, investigation, prosecution, and examination in court regarding a criminal case which the person has heard, seen, and/or experienced in the position of a suspect.]

Edyono $^{30}$ also adds that a cooperative perpetrator must be a witness and a suspect. This definition, of course, does not include a reporter or informant, who may not be included in the definition of a witness above, but has a significant role in providing information about the case. In other words, it refers to an actual perpetrator who has the status of a convict.

In the determination process, a convict who applies to be a justice collaborator must wait for an assessment of whether the provided information has value to uncover a larger crime. Law enforcement officers carry out the information assessment based on the Criminal Procedure Code to legalize the action. The Criminal Procedure Code regulates the limitations of law enforcers' power to protect public rights. To be precise, some articles of the Criminal Code prohibit law enforcement officers from carrying out arbitrary actions. ${ }^{31}$

\footnotetext{
28 Supriyadi Widodo Edyono, "Prospek Pelindungan Justice Collaborator di Indonesia: Perbandingan di Amerika Serikat dan Eropa", Jurnal Perlindungan Saksi dan Korban, Vol. 1, No. 1, 2011, p. 110.

29 The Ecision of the Constitutional Court of the Republic of Indonesia Number 065/PUU-VII/2010 has expanded the understanding of witnesses in the Criminal Procedure Code.

30 Academic Text of the Draft of the Republic of Indonesia Number 31 of 2014 on the Amendments to Law Number 13 of 2006 on the Protection of Witnesses and Victims, p. 21.

31 Anggit Sinar Sitoresmi, "Sanksi Aparat Penegak Hukum yang Melanggar KUHAP dalam Menanggulangi Kejahatan", Jurnal Hukum Jurisprudence, Vol.8, No. 2, 2018, p. 72.
} 
Meliala argues that the status of justice collaborator can only be done in the pre-adjudication and adjudication phase. In other words, the status of justice collaborator is not rightly given to prisoners. This study is of the position to see that Meliala's opinion can only be justified from the point of view of an Integrated Criminal Justice System. It is a mechanism or form of legal certainty as a legal objective. However, from the other perspectives, namely justice and benefit, the main purpose of the concept is certainly not fulfilled. As it is known that the initial and main goal of the concept is the dismantling of an organized crime by utilizing information from a perpetrator who had been caught. It is expected that the information from the perpetrator is true because the perpetrator is an "insider". Thus, the side of expediency as a legal goal can be achieved.

The European Union, since 1996, has produced a decision that focuses on the suppression of terrorism and organized crime by exchanging information with cooperative perpetrators. Article 1 of the Recommendations (2005) 9 of The Collaboration of Justice reads as follows. ${ }^{32}$

"a collaborator of justice gets defined as any person who faces criminal charges, or was convicted, of having taken part in an association of criminals or other criminal organization of any kind, or in organized crime offense but agrees to co-operate with criminal justice authorities, particularly by giving information about the criminal association or organization or any criminal offense connected with organized crime or other serious offense."

The resolutions of the member states of the European Union defines justice collaborator as follows. ${ }^{33}$

"Supplying information useful to the competent authorities for investigative and evidential purpose, on the composition, structure or activities of criminal organization, on link with other criminal groups and/or on offenses which this organizations or groups have committed or might commit."

In return for a criminal who is willing to collaborate with law enforcement as a justice collaborator, the safety will be guaranteed, and a leniency can be given. However, not all member states of the European Union implement the resolution into their positive law in their respective states.

"A few member states do not feel an urgent need for a regulation concerning the collaborator with justice. The reasons differ: they are only very seldom confronted with the types of crimes for which the

\footnotetext{
32 Gert Vermeulen, EU Standards in Witness Protection and Collaboration with Justice, Antwerp (Belgium): Maklu Publishers, 2005, p. 66.

$33 \quad$ Ibid, p. 67.
} 
figure is effective, they have moral objections to the waiving or mitigating of punishment, etc." ${ }^{34}$

Other states of the world, which are member-states of the 2003 United Nations Convention Against Corruption, then formulate a rule of laws to protect and reward a justice collaborator. However, there are differences in each state on the definition of a justice collaborator. Some states that can only grant justice collaborator status to suspects and/or defendants; and some states grant justice collaborator status to prisoners.

Macedonia already has a statutory regulation regarding the legal protection for witnesses starting from May 26, 2005. It has implemented privileges for justice collaborators (later known as Collaborator to Justice). ${ }^{35}$ In Article 2 number (2) of the Law on Witness Protection of Macedonia, the meaning for Collaborator to Justice is as follows. ${ }^{36}$

"a person against whom an indictment is filled, is convicted, or member of a criminal group, gang or other association, or has participated in committing a crime in the area of organized crime, but has agreed to cooperate with the bodies authorized to identify, prosecute and trial the criminal acts, particularly to give a statement in capacity of witness in the criminal procedure, related to the criminal group, band or other association or to any other criminal act connected with organized crime."

The law expressly determines a convict to be given the opportunity to apply as a justice collaborator.

The idea of justice collaborators in Macedonia was inspired by the concept of plea-bargaining in the Anglo-American legal system. However, the implementation is slightly different, especially in terms of the presence of legal advisors in the process of bargaining with the prosecutor. The 2010 Criminal Procedure Code (the CPC of Macedonia or Macedonian Criminal Procedure Code) stipulates that in terms of bargaining for punishment between the justice collaborator and the prosecutor, it is only allowed to transfer the type of crime, not change the indictment. The concept is defined as follows. ${ }^{37}$

\footnotetext{
$34 \quad$ Ibid, p. 65.

35 Rahmi Dwi Sutanti, “Kebijakan Formulasi Saksi Pelaku yang Bekerjasama (Justice collaborator) sebagai Alasan Peringanan Pidana dalam Rangka Pembaruan Hukum Pidana Nasional", Tesis, Semarang: Universitas Diponegoro, 2013, p. 162.

36 The Law on Witness Protection of Macedonia.

37 Boban Misoski, "Delayed Justice - Macedonian Experience with Guilty Plea and Sentence Bargaining", SEEU Review, Vol. 11, No. 1, 2016, pp. 99-101.
} 


\begin{abstract}
"With the enactment of the new Criminal Procedure Code in 2010, Macedonian legislators have created a modern criminal justice system mainly inspired by the Anglo-American adversarial system. The main reasons for the vast reform of the criminal justice system in Macedonia were to increase the efficiency and reduce the time of the criminal procedures... by these provisions, we can notice that Macedonian sentence bargaining process has, in a way, differed from its original US concept, due to the fact that it requests the mandatory presence of the defense lawyer (Art. 74 CPC, 2010) during the whole sentence bargaining process."
\end{abstract}

In Macedonia, the Witness Protection Department is the institution authorized to grant justice collaborator status. There are limits to several types of criminal acts that can include the involvement of a justice collaborator. Some crime acts, such as resistance to a legitimate government (treason), is against humanity and applicable international law, organized crimes, and some crimes that are punishable by punishment at least 4 (four) years. The Ministry of Witness Protection in Macedonia offers a change in the type of punishment for justice collaborators by not changing the prosecution's charges. ${ }^{38}$

Another European state, Albania, also has detailed legal rules regarding Justice collaborators (also called Collaborator of Justice). The Law Number 9205 dated March 15, 2004 or known as the Law on the Justice Collaborator and Witness Protection reads as follows. ${ }^{39}$

"There is a special judicial and public awareness of the criminal proceedings involving individuals who are accused of committing serious crimes, especially homicides, organized crime, corruption, and trafficking, in Albania. The novel dimension of witnesses testifying in organized crime, trafficking and terrorism cases has created a climate of serious intimidation." 40

Article 2 (b) determines the meaning of Collaborator of Justice as follows. ${ }^{41}$ "a person that serves a criminal sentence or a defendant in a criminal proceeding, towards whom special measures of protection have been applied due to collaboration, notifications and declarations made during the criminal proceeding on the offenses provided in letter $e$ of this article, and for these reasons is in a real, concrete or serious danger." 
According to this law, Albania clearly stipulates that apart from a defendant, a convict can also be given the opportunity to become a justice collaborator. The institution that is then given the authority to determine the status of justice collaborator is the Prosecutor as the Public Prosecutor. In Albania, a person who has been designated as a justice collaborator does not receive criminal leniency but only protection of the safety of themselves and their family. ${ }^{42}$

In Norway, justice collaborator is not only limited to the status of suspects, defendants, or even convicts. Criminal reductions can also be applied to criminals who have prevented the effects that may arise or repaired the damage because of their actions before knowing that they are suspects. ${ }^{43}$

The Section 59 of The General Civil Penal Code of Norwegia (Act of May 22, 1902, Number 10, with subsequent amendments, the latest made by the Act of December 21, 2005, No. 0131), Legislation Department of Norwegian Ministry of Justice 2006 reads as follows. ${ }^{44}$

"The provisions of section 58 shall also apply to a person who before he knows that he is suspected as far as possible and substantially prevented the harmful consequences of the act or has restored the damage cause thereby If the person charged has made an unreserved confession, the court shall take this into account when passing sentence. The court may reduce the penalty below the minimum prescribed for the act and to a milder form of penalty."

In Norway, the institution authorized to determine the status of justice collaborators is the Police. The criminal acts that can cover the involvement of collaborators are the ones with participation (deelneming). Someone who has been designated as a justice collaborator will get a special minimum penalty/criminal reduction and get a reduction based on the type of crime. ${ }^{45}$

In the United States of America, justice collaborator is regulated under the Bureau of Prisons. The task is to monitor and control witnesses who are in detention or convict status as well as to prepare administrative needs. ${ }^{46}$ In the criminal justice system of the state, the Attorney General has the authority to assess and evaluate applications for justice collaborators.

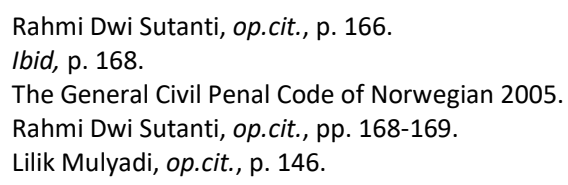


"As Robert H. Jackson (1940) once famously observed, the prosecutor has more control over life, liberty, and reputation, than any other person in America. Prosecutors often supervise investigative officials (including police) and may actively engage in a criminal investigation." 47

Attorney Generals and public prosecutors in every state of the United States are officials who have discretionary authority over criminal cases. They can do pleabargaining, which is a kind of discretionary right against perpetrators of crimes, especially organized crime cases. The Public Prosecutor has the most important role in the criminal justice system. The district attorney's office has the power to handle cases, including not bringing a criminal case to court. Some cases deserved to be accepted for trial, while other cases were declared unacceptable. ${ }^{48}$ Pleabargaining applied when the perpetrator admits their actions so that the prosecutor can give a motion to the judge for a reduced sentence.

"Prosecutorial discretion in the plea-bargaining process plays an important role in determining the conviction crime. Serious charges that were initially filed against a defendant may be reduced to less serious ones, and concurrent charges involving less serious crimes may be dropped altogether." 49

Plea Bargaining in a concept in which the Prosecutor as an assessor of information from the applicant is not allowed to give a promise in the form of commutation of sentence but states in the indictment which then submits a motion to the judge for commutation of sentence. The types of crimes in the United States prioritized for justice collaborators are organized crime, extortion, and drug trafficking. ${ }^{50}$

From some examples above, it can be concluded that those states prioritize benefits from cooperation between law enforcement officers and criminals. The purpose is information on an organized crime network that has a major impact on society, especially on the security of a state by making an easier arrangement in granting status justice collaborator for a convict of crimes that endanger state security. However, the formal criminal law in each country varies according to the constitution and morals.

Based on the main purpose of the concept of justice collaborator, then it should not limit the status of people who apply to be justice collaborators. An inmate who certainly has information about a serious and organized crime network

\footnotetext{
47 Andrew F. Daughety and Jennifer F. Reinganum, "Reducing Unjust Convictions: Plea Bargaining, Trial, and Evidence Suppression/Disclosure", Journal of Law Economics and Organization, Vol. 36, No. 2, 2018, p. 1.

48 Soediro, "Perbandingan Sistem Peradilan Pidana Amerika Serikat dengan Peradilan Pidana di Indonesia", Jurnal Kosmik Hukum, Vol. 19, No. 1, 2019, p. 56.

49 Carlos Berdejó, “Criminalizing Race: Racial Disparities in Plea Bargaining”, Boston College Law Review, Vol. 59, No. 4, 2018, p. 1197.

$50 \quad$ Lilik Mulyadi, op.cit., p. 153.
} 
can be involved in cooperation with law enforcement officials. This study is of the position to see the use of the justice collaborator concept as more feasible than the use of crown witness (splitting the status) as regulated in the Criminal Procedure Code, which is considered to have violated legal principles non-self-incrimination and human rights.

The implementation of the concept of justice collaborator is also more attractive to a person who is a prisoner because of the guarantee in the law that provides protection to witnesses and victims in the form of determining remission and parole, although in the pre-adjudication process and adjudication process, the convict did not volunteer as a justice collaborator. This distinguishes the concept of justice collaborator with the concept of a crown witness that does not provide security and protection guarantees.

The assessment of the importance of providing opportunities for convicts to collaborate with law enforcement officers to dismantle their crime networks is also a form of realizing the value of justice as a legal goal. The value of justice as one of the legal ideals was initiated by Radbruch. Aristotle's view of justice is divided into two main points. The first is distributive justice as a concept of justice in which everyone gets something that should be right. The second is the thought of commutative justice, namely the determination of fair rights between several human beings who are then considered equal. Based on the idea of Aristotle, it can be concluded that there is a main idea, namely distributive justice, as an obligation of the government for its people to determine what the people can ask for. ${ }^{51}$

Convicts as criminals who are undergoing a criminal period of deprivation of liberty must still be considered as citizens, and the government must guarantee their rights. The 1945 Constitution of the Republic of Indonesia stipulates that every citizen has the right to be given protection for their personally including their family members, honor, dignity, and property under her/his control, and has the right to a sense of security and to be given protection against threats of fear to do or not to do something that is already a human right. ${ }^{52}$

Some of the principles contained in the Universal Declaration of Human Rights (UDHR) are intended for all individuals without exceptions, including those with the status of convicts. The UDHR principles regulate that no person may be tortured or treated and given inhumane or humiliated punishments (Article 5); and all human beings are considered equal before the law and have the right to legal protection that is not discriminatory or without discrimination, every human being has the right to be given equal protection from any discriminatory treatment that is not in

\footnotetext{
51 Bahder Johan Nasution, “Kajian Filosofis tentang Keadilan dan Hukum (Dari Pemikiran Klasik hingga Modern)", Jurnal Al-Hikam, Vol. 11, No. 2, 2016, pp. 253-254.

52 See Article 28 G (1) of the 1945 Constitution of the Republic of Indonesia.
} 
line with this statement (Article 7). The Universal Declaration of Human Rights was accepted and promulgated by the United Nations General Assembly on December 10,1948 , through resolution number $217 \mathrm{~A}$ (III)..$^{53}$

Article 10 (1) of the International Covenant on Civil and Political Rights (ICCPR) states that "Everyone who is deprived of his liberty must be treated humanely and with respect for the inherent dignity of the human being". ${ }^{54}$ In 1963, thought about correctional facilities was initiated by the Minister of Justice Sahardjo. It covered imprisonment, in addition to cause suffering to people who are being sentenced as a result of the deprivation of freedom of free activity. It must also direct people who are being convicted not to repeat their actions, to teach so that they become a useful part of the socialist society. ${ }^{55}$

The opinion that justice collaborator can only be applied to the preadjudication and adjudication phases need to be changed. The assumption that all information has been given to the public prosecutor in the adjudication phase so that prisoners are deemed unfit to apply as justice collaborators can be interpreted as irrelevant to the value of expediency as a legal goal.

Another important opportunity to be a justice collaborator is to realize the value of expediency as a legal goal. According to Muladi and Arief, justice is not just to take revenge or retaliation to people who have committed a crime, but it has specific useful purposes. ${ }^{56}$ The Deputy Chairperson of the Witness and Victim Protection Agency, Edwin Partogi Pasaribu ${ }^{57}$ argues that to ensnare perpetrators of organized crime such as corruption is not easy. State also needs optimal returns on losses that can be saved. On the other hand, the deterrent effect and warning to anyone not to commit a similar crime must be clear in the judicial process.

The minor perpetrator who becomes justice collaborator must provide the facts of an event. Corruption is a crime that has a major impact on the success of development, enforcement of the rule of law, and democracy. This is because it is an effort to combat obligatory procedures with targeted procedures, including the attitude of collaborating with minor perpetrators. ${ }^{58}$

Based on the original concept of justice collaborator as a means to dismantle organized crime, making convict as justice collaborator as determined by the Law of Witness and Victim Protection can realize the main goal of the justice collaborator.

Furthermore, in the stages of the procedure for granting justice collaborator status to prisoners as in the Indonesian laws and regulations, there are still

\footnotetext{
53 Penny Naluria Utami, "Keadilan Bagi Narapidana di Lembaga Pemasyarakatan”, Jurnal Penelitian Hukum De Jure, Vol. 17, No. 3, 2017, p. 382.

Ibid, p. 383.

Ibid, p. 384.

Muladi and Barda Nawawi Arief, Teori-teori dan Kebijakan Pidana, Bandung: Alumni, 1992, pp. 10-11.

Edwin Partogi, "Justice Collaborator", https://kumparan.com/edwin-partogi/justice-collaborator1sv7nVWOD10/full, accessed on April 2020.

58 Ibid.
} 
problems, especially in terms of rewards in the form of parole and remission. Article 10A paragraph (5) of the Law Number 31 of 2014 on the Amendments to the Law Number 13 of 2006 on the Protection of Witnesses and Victims determines that the LPSK provides written recommendations to the Ministry of Law and Human Rights.

Based on Article 7 paragraph (2) of Law Number 12 of 2011 on the Establishment of Legislations, of course, the Law Number 31 of 2014 has a higher hierarchy than Government Regulation Number 32 of 1999. It is the principle of lex superior derogat legi inferiori. ${ }^{59}$ Thus it can be said that the LPSK can determine whether a convict can be designated as a justice collaborator or not. The convict is entitled to remission and or parole as a reward for the cooperation. However, based on the authority to investigate a criminal act, the LPSK does not have that authority like the Indonesian Police, the Indonesian Attorney General's Office, the KPK, and the BNN. This study is of the position to see that the purpose of justice collaborator status is unable to be realized.

These problems should not hinder the granting of rights to convict to obtain justice collaborator status, remission, and parole. However, in the implementation, it must still be realized in a clear procedural law arrangement. Therefore, the implementation does not raise doubts targeting the law enforcement officials, including that there is no conflict between one statutory regulation. So that the legal certainty side as one of the legal goals can be realized.

\section{Conclusion}

There are obstacles to provide protection for justice collaborators based on the legal aspects. The laws and regulations are still vague, partial, and sectoral - for example, the Law Number 14 of 2006 in conjunction with the Law Number 31 of 2014 and the Government Regulation Number 32 of 1999 on the Terms and Procedures for the Implementation Rights of Correctional Inmates. The regulations have not yet determined procedures, mechanisms, and systems for the process of revealing the facts with the help of a justice collaborator. In the legal norm, there are also conflicts between laws and regulations, which in their application will not be able to realize the main objective of justice collaborator, namely the disclosure of larger crimes.

The urgency of the justice collaborator concept for convicts is to be involved in cooperation with law enforcement officers. This will be very helpful, especially in disclosing crimes that are categorized as organized crimes. An inmate certainly has information about a serious and organized crime network. In addition, it is also

59 See Article 7 paragraph (2) of the Law Number 12 of 2011 on the Establishment of Legislation. 
important to provide opportunities for the convict to collaborate with law enforcement officers as justice collaborators to dismantle their crime networks. In addition, this study views that it is a form of realization of the value of expediency as a legal goal.

\section{References}

\section{Books}

Andi Andojo Soetjipto, Menyongsong dan Tunaikan Tugas Negara Sampai Akhir: Sebuah Memoar, Granit, Jakarta, 2007.

Andi Hamzah, Sistem Pidana dan Pemidanaan di Indonesia, Pradnya Paramita, Jakarta, 1993.

- Pemberantasan Korupsi Melalui Hukum Pidana Nasional dan Internasional, Edisi Revisi, Raja Grafindo Persada, Jakarta, 2007.

Firman Wijaya, Whistleblower dan Justice Collaborator dalam Perspektif Hukum, Penaku, Jakarta, 2012.

Lilik Mulyadi, Perlindungan Hukum Whistleblower \& Justice Collaborator dalam Upaya Penanggulangan Organized Crime, PT Alumni, Bandung, 2015.

Muladi and Barda Nawawi Arief, Teori-Teori dan Kebijakan Pidana, Alumni, Bandung, 1992.

O. C. Kaligis, Antologi Tulisan Ilmu Hukum Jilid 1, PT Alumni, Bandung, 2007.

Peter Mahmud Marzuki, Penelitian Hukum, Edisi Revisi, Prenadamedia Group, Jakarta, 2017.

Ross Poole, Moralitas dan Modernitas, di Bawah Bayang-Bayang Nihilisme, Kanisius, Yogyakarta, 1993.

Vermeulen, Gert, EU Standards in Witness Protection and Collaboration with Justice, Maklu Publishers, Antwerp (Belgium), 2005.

\section{Other Documents}

Anggit Sinar Sitoresmi, "Sanksi Aparat Penegak Hukum yang Melanggar KUHAP dalam Menanggulangi Kejahatan", Jurnal Hukum Jurisprudence, Vol. 8, No. 2, 2016.

Berdejó, Carlos, "Criminalizing Race: Racial Disparities in Plea Bargaining", Boston College Law Review, Vol. 59, No. 4, 2018.

Beqiri, Romina, "The Immediate Demand for an Efficient Protection of Witnesses of Justice in Albania", RAIS Journal for Social Sciences, Vol. 2, No. 1, 2018.

Dani Prabowo, "Kejati DKI: Penggunaan Saksi Mahkota Masih Jadi Perdebatan", https://nasional.kompas.com/read/2015/07/31/08195591/Kejati.DKI.Pengguna an.Saksi.Mahkota.Masih.Jadi.Perdebatan.

Daughety, Andrew F. and Jennifer F. Reinganum, "Reducing Unjust Convictions: Plea Bargaining, Trial, and Evidence Suppression/Disclosure", Journal of Law Economics and Organization, Vol. 36, No. 2, 2018. 
Edwin Partogi, "Justice Collaborator", https://kumparan.com/edwinpartogi/justice-collaborator-1sv7nVWOD10/full.

Frassminggi Kamasa, "Kejahatan Kerah Putih, Kontraterorisme dan Perlindungan Hak Konstitusi Warga Negara dalam Bidang Ekonomi", Jurnal Konstitusi, Vol. 11, No. 4, December 2014.

Henry Donald Lbn. Toruan, "Pertanggungjawaban Pidana Korporasi”, Jurnal Rechts Vinding, Vol. 3, No. 3, 2014.

I Made Sukadana, Amiruddin, Lalu Parman, "Alat Bukti Keterangan Saksi Mahkota dalam Perkara Pidana Pencurian”, Jurnal Law Reform, Vol. 14, No. 2, 2018.

Misoski, Boban, "Delayed Justice - Macedonian Experience with Guilty Plea and Sentence Bargaining", SEEU Review, Vol. 11, No. 1, 2016.

Penny Naluria Utami, "Keadilan Bagi Narapidana di Lembaga Pemasyarakatan", Jurnal Penelitian Hukum De Jure, Vol. 17, No. 3, 2017.

Rahmi Dwi Sutanti, Kebijakan Formulasi Saksi Pelaku yang Bekerjasama (Justice Collaborator) sebagai Alasan Peringanan Pidana dalam Rangka Pembaruan Hukum Pidana Nasional, Tesis, Semarang: Universitas Diponegoro, 2013.

Satria, Hariman, "Menakar Perlindungan Justice Collaborator, Quo Vadis Justice Collaborator", Jurnal Konstitusi, Vol. 13, No. 2, 2016.

Soediro, "Perbandingan Sistem Peradilan Pidana Amerika Serikat dengan Peradilan Pidana di Indonesia", Jurnal Kosmik Hukum, Vol. 19, No. 1, 2019.

Supriyadi Widodo Edyono, "Prospek Pelindungan Justice Collaborator di Indonesia: Perbandingan di Amerika Serikat dan Eropa", Jurnal Perlindungan Saksi dan Korban, Vol. 1, No. 1, 2011.

\section{Legal Documents}

United Nations Convention Against Transnational Organized Crime 2000.

United Nations Office on Drugs and Crime (UNODC), Good Practices for the Protection of Witnesses in Criminal Proceedings Involving Organized Crime, United Nations 2008.

The Law Number 8 of 1981 on the Book of Criminal Code [Undang-Undang Nomor 8 Tahun 1981 tentang Kitab Undang-Undang Hukum Acara Pidana].

The Law Number 7 of 2006 on the Ratification of the 2003 United Nations Convention against Corruption 2003 [Undang-Undang Nomor 7 Tahun 2006 tentang Pengesahan United Nation Convention Against Corruption (Konvensi Perserikatan Bangsa-Bangsa Anti Korupsi 2003)].

The Law Number 5 of 2009 on the Approval of the United Nations Convention on the Transnational Organized Crime [Undang-Undang Nomor 5 Tahun 2009 tentang Pengesahan United Nations Convention Against Transnational Organized Crime]. 
The Law Number 12 of 2011 on the Establishment of Legislation [Undang-Undang Nomor 12 Tahun 2011 tentang Pembentukan Peraturan Perundang-undangan].

Law Number 31 of 2014 on the Amendments to the Law Number 13 of 2006 on Protection of Witnesses and Victims [Undang-Undang Nomor 31 Tahun 2014 tentang Perubahan Atas Undang-Undang Nomor 13 Tahun 2006 tentang Perlindungan Saksi dan Korban].

Government Regulation Number 099 of 2012 on the Amendment to the Second Government Regulation Number 032 of 1999 on the terms and procedures for the implementation of right of inmates [Peraturan Pemerintah Nomor 099 Tahun 2012 mengenai Perubahan Kedua Peraturan Pemerintah Nomor 032 Tahun 1999 tentang Syarat dan Tata Cara Pelaksanaan Hak Warga Binaan Pemasyarakatan].

Joint Regulation of the Minister of Law and Human Rights, the General Attorney, the Chief of National Police, the Corruption Eradication Commission, the Witness and Victim Protection Agency No. M.HH-112.HM.03.02.Th.2011, Number PER-045/A/JA/12/2011, Number 01 of 2011, No. KEPB-002/00155/12/2011, and Number 04 of 2011 on Protection for Whistleblowers, Witness-Reporter, and the Witness Perpetrators Who are Cooperative [Peraturan Bersama Menteri Hukum Dan Hak Asasi Manusia Republik Indonesia, Jaksa Agung Republik Indonesia, Kepala Kepolisian Negara Republik Indonesia, Komisi Pemberantasan Korupsi Republik Indonesia, Ketua Lembaga Perlindungan Saksi dan Korban Republik Indonesia No. M.HH112.HM.03.02.Th.2011, No. PER-045/A/JA/12/2011, No. 01 tahun 2011, No. KEPB-002/001-55/12/2011, dan No. 04 Tahun 2011 tentang Perlindungan bagi Pelapor, Saksi Pelapor, dan Saksi Pelaku yang Bekerja Sama].

Circular Letter of the Supreme Court of the Republic of Indonesia (SIM) Number 11 of 2011 on the Treatment of Criminal Whistleblowers and Witness Perpetrators are Cooperative to Work Together (Justice Collaborator) in Specific Crime [Surat Edaran Makamah Agung Republik Indonesia (SEMA) No. 11 tahun 2011 tentang Perlakuan Bagi Pelapor Tindak Pidana (Whistle Blower) dan Saksi Pelaku yang Bekerja Sama (Justice Collaborator) di dalam Perkara Tindak Pidana Tertentu].

The Civil Penal Code of Norwegian 2005.

The Law on Witnesses Protection of Macedonia 2005.

The Law Number 9205 on the Justice Colaborator and Witness Protection of Ibania. 